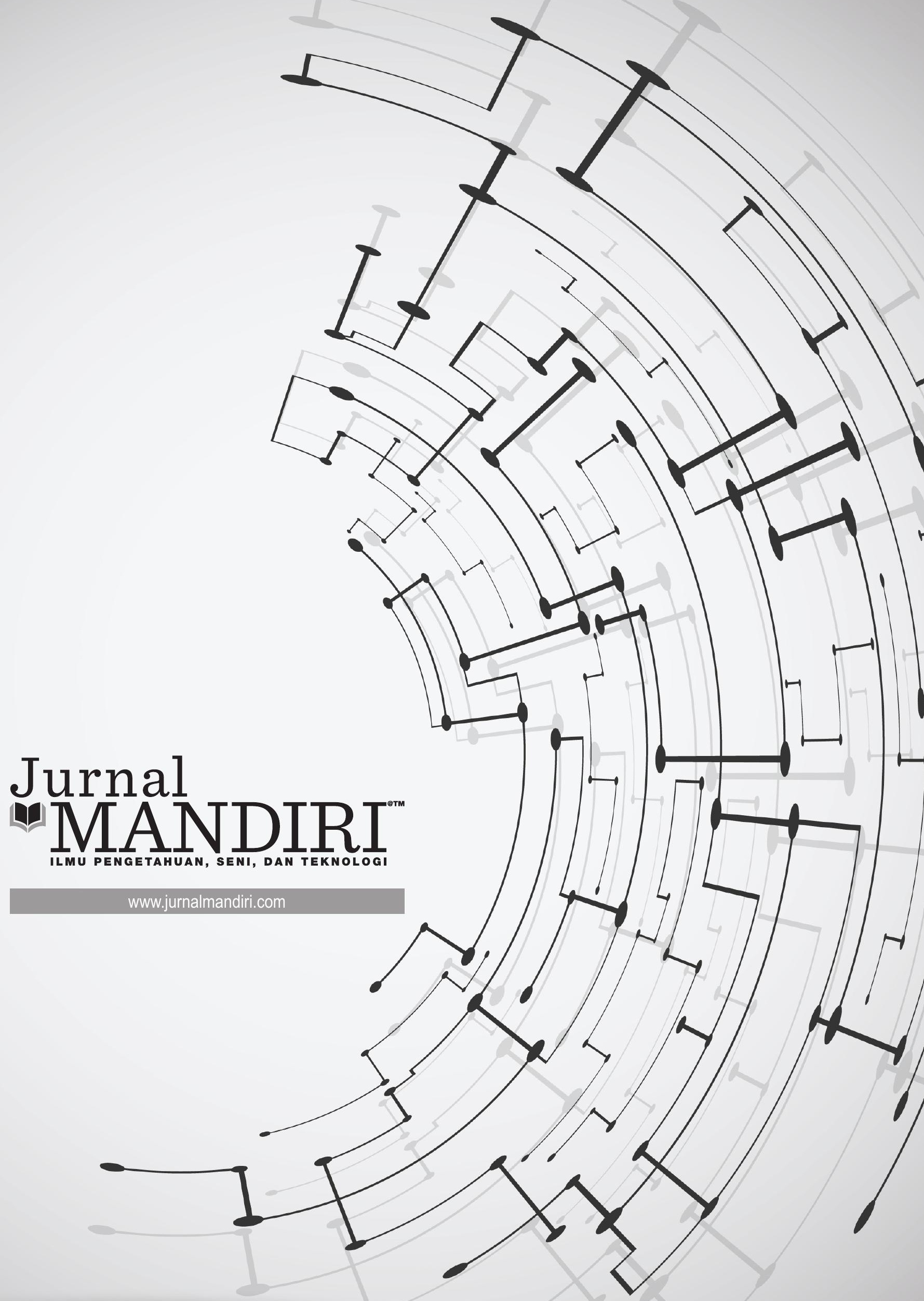


ISSN : 2580-3220, E-ISSN : 2580-4588

J. Mandiri., Vol. 3, No. 2, Desember 2019 (307 - 313)

C2018 Lembaga Kajian Demokrasi

dan Pemberdayaan Masyarakat (LKD-PM)

DOI : https://doi.org/10.33753/mandiri.v3i2.92

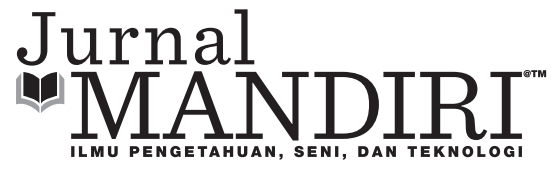

\title{
Pengaruh Dow Jones Indeks, Strait Time, dan Hang Sheng Terhadap Indeks Harga Saham Gabungan Dengan Pendekatan Error Correction Model
}

\author{
Tiar Lina Situngkir \\ Fakultas Ekonomi dan Bisnis, Universitas Singaperbangsa Karawang \\ tiarlina.situngkir@fe.unsika.ac.id
}

\begin{abstract}
Abstrak
Tujuan penelitian ini adalah menganalisis pengaruh Dow Jones Index, Strait Times Index dan Hang seng Indeks terhadap indeks harga saham gabungan. Metodologi yang digunakan dalam menganalisa adalah Error Correction Model. Hasil penelitian menemukan bahwa DJI dalam jangka pendek dan panjang berpengaruh positif tidak signifikan. STI dalam jangka pendek dan panjang berpengaruh berpengaruh positif signifikan. HSE dalam jangka pendek dan panjang berpengaruh negatif tidak signifikan. Simpulan secara simultan dalam penelitian ini terbukti paling tidak terdapat satu variabel independen berpengaruh signifikan.
\end{abstract}

Kata Kunci : DJI, STI, HSE, IHSG, ECM

\section{Abstract}

The objective of this research is to analyse whether Dow Jones Index, Strait Times Index and Hang Seng Index, each has a significant effect on Composite Stock Index. The methodology of analysis of this research is Error Correction Model. The result of research found that in the short term Dow Jones has no significant while in long term it has positive and significant impact on Indonesian Composite Stock Index. Summary In the short and long term Strait Time Index has positive and significant impact. In short and long term Hang Seng Index has no significant on Composite Stock Index.

Keywords : DJI, STI, HSE, IHSG, ECM

\section{PENDAHULUAN}

Pasar modal memiliki peran penting sebagai sarana investasi yang berguna bagi pembangunan, dalam hal ini nilai harga saham menjadi pertimbangan yang sangat penting. Situasi dunia yang semakin menggelobal memberikan dampak pada nilai ekonomi, dimana harga saham tidak lagi hanya dipengaruhi oleh kondisi ekonomi dan fenomena yang terjadi di dalam negeri, gejolak ekonomi dan peristiwa-peristiwa luar biasa yang terjadi di luar negeri turut mempengaruhi nilai saham. Oleh sebab itu, upaya penciptaan iklim investasi kondusif oleh pemerintah penting untuk segera terwujud, sebab terkait erat dengan perbaikan kondisi makro ekonomi domestik. Semakin stabilnya kondisi makroekonomi, maka investor merasa semakin aman dan nyaman akan dana yang diinvestasikannya.

Nasution (2003) berpendapat sangat penting untuk menjaga stabilitas sistem keuangan saat ini dan di masa mendatang, karena semakin sehat sektor keuangan di suatu negara, semakin sehat pula perekonomian, demikian pula sebaliknya. Telah dipahami bahwa sistem keuangan memegang peranan yang sangat penting. Dalam perekonomian, seiring dengan fungsinya untuk 
menyalurkan dana dari pihak yang berkelebihan dana kepada pihak-pihak yang membutuhkan dana. Apabila sistem keuangan tidak bekerja dengan baik, maka perekonomian menjadi tidak efisien dan pertumbuhan ekonomi yang diharapkan tidak akan tercapai. Dengan demikian perkembangan sektor keuangan, termasuk di dalamnya pasar modal, merupakan salah satu indikator yang perlu diperhatikan untuk menjaga kesehatan atau kestabilan perekonomian.

Rahamis (2014) meneliti bahwa pasar modal yang tergolong maju seperti Amerika dan Inggris memiliki pengaruh yang kuat terhadap pasar modal di negara lain, efek penularan (contagion effect) tersebut menyebabkan terjadinya hubungan atau interaksi pasar modal yang membentuk suatu integrasi pasar modal. Pergerakan harga saham, obligasi, dan sebagainya di pasar modal suatu negara dipengaruhi oleh persepsi investor terhadap kondisi pasar modal tersebut. Persepsi ini pada akhirnya akan mempengaruhi dana investasi yang masuk ke suatu negara, sehingga mempengaruhi keadaan perekonomian negara yang bersangkutan. Hal ini terjadi di semua negara, seperti di Amerika Serikat, Eropa, dan Asia, termasuk Indonesia.

Ketika terjadi krisis di Amerika Serikat tahun 2008, tidak dapat terelakkan bahwa semua negara di dunia dan Asia juga terkena dampaknya, khususnya Indonesia peristiwa ini berpengaruh signifikan terhadap pasar modal Indonesia. Pergerakan Indeks Harga Saham Gabungan (IHSG) terbukti memberikan respon yang searah terha dap gejolak Dow Jones Industrial Average (DJIA). Perubahan Dow Jones Industrial Average (DJIA) ini lebih berperan dalam menjelaskan pergerakan Indeks Harga Saham Gabungan (IHSG) sehingga hal ini menunjukkan pasar modal Indonesia masih sangat dipengaruhi oleh pasar modal asing, sehingga jika terjadi shock pada indeks saham besar luar negeri akan dengan mudah menimbulkan kepanikan di kalangan investor domestik Nezky (2013).

Batareddy, Gopalaswamy, Huang (2012) meneliti hubungan jangka panjang antara pasar modal negara berkembang di Asia dalam hal ini India, Cina, Korea Selatan, dan Taiwan sesama antar negara juga terhadap negara maju seperti Amerika dan Jepang, dan menemukan bahwa ada korelasi antara negara di Asia tersebut dengan Amerika dalam hubungan jangka panjang namun antara negara tetangga di Asia, justru tidak saling mempengaruhi. Gopalaswamy, Babu (2013) menganalisa hubungan jangka pendek antara pasar modal Amerika dan pasar modal Asia seperti Cina, India, sebagai negara Asia yang berkembang, Hongkong, Singapura, Korea Selatan, dan Taiwan sebagai negara industri baru untuk mengukur dinamika hubungan antar negara tersebut pada saat setelah krisis 1997 dan 2008. Kesimpulan yang ditemukan adalah pasar modal Amerika sangat mendominasi atas pasar modal di Asia. Apabila terjadi gejolak di pasar modal di Amerika akan dengan segera mempengaruhi pasar modal Asia dengan krisis yang berbeda-beda di masingmasing negara Asia.

Ekadjaja (2014) meneliti pengaruh indeks harga bursa regional terhadap indeks harga saham gabungan. Hasil penelitian menemukan adanya hubungan dari masing-masing variabel terhadap indeks harga saham gabungan.

Berdasarkan hasil penelitian yang terdahulu, penulis ingin meneliti kembali faktor-faktor makroekonomi apa saja yang berpengaruh terhadap IHSG. Yang membedakan pada penelitian kali ini, yang diteliti adalah hubungan faktor makroekonomi yang terdiri dari kurs, tingkat suku bunga, inflasi, dan dua indeks gabungan sebagai pembanding yaitu Indeks saham STI dan Indeks Saham Dow Jones terhadap indeks harga saham gabungan dalam pengaruh jangka pendek dan panjang dengan menggunakan model error correction model dengan periode dari tahun 20062016. Berdasarkan kajian yang ada pada latar belakang di atas maka perumusan masalah dalam penelitian ini adalah sebagai berikut :

1. Apakah indeks Dow Jones berpengaruh signifikan terhadap pergerakan indeks harga saham gabungan dalam jangka pendek dan jangka panjang?

2. Apakah indeks Strait Time berpengaruh signifikan terhadap pergerakan indeks harga saham gabungan dalam jangka pendek dan jangka panjang? 
3. Apakah indeks Hang Seng berpengaruh signifikan terhadap pergerakan indeks harga saham gabungan dalam jangka pendek dan jangka panjang?

4. Apakah variabel-variabel independen secara simultan berpengaruh signifikan terhadap indeks harga saham gabungan.?

\section{METODE}

Penelitian ini menggunakan metode korelasional karena bermaksud untuk melakukan pemaparan serta melakukan analisis mengenai pengaruh jangka pendek dan jangka panjang dari Dow Jones Index (DJI), Strait Time Index (STI) serta Hang Seng Index (HSE) terhadap Indeks Harga Saham Gabungan (IHSG) di Indonesia. Model Error Correction Model (ECM) digunakan untuk menjawab persamalahan penelitian yaitu menganalisis pengaruh jangka pendek dan jangka panjang dari variabel independen (Indeks Saham Down John, Strait Time Index dan Hang Seng Indeks) terhadap variabel dependennya dalam hal ini adalah Indeks Harga Saham Gabungan (IHSG).

Berdasarkan kerangka pemikiran yang telah dijelaskan sebelumnya, terdapat dua variabel yang akan dianalisis. Keempat variabel tersebut yaitu variabel bebas (Independent Variable), variabel terikat (Dependent Variable).

\section{Variabel Bebas (Independent Variable)}

Variabel independen yang digunakan dalam penelitian ini terdiri dari Dow Jones Index (DJI), Strait Time Index (STI) serta Hang Seng Index (HSE)

\section{Variabel Terikat (Dependent Variable)}

Variabel terikat adalah variabel tidak bebas atau variabel yang dipengaruhi oleh variabel independen. Variabel dependen yang digunakan dalam penelitian ini adalah Indeks Harga Saham Gabungan (IHSG).

Dalam penelitian ini terdapat dua jenis variabel yang akan digunakan yaitu variabel bebas (independent variabel) dan variabel terikat (variabel dependent).

Metode pengumpulan data dilakukan dengan purporsive sampling yaitu pemilihan anggota sampel yang didasarkan pada kriteriakriteria atau ciri-ciri tertentu yang dimiliki sampel itu sehingga dapat memperoleh sampel yang representative. Sampel yang dipilih adalah data time series untuk bulanan periode 20062016. Data yang digunakan merupakan data sekunder yang berasal dari dua sumber yaitu Statistik Ekonomi Keuangan Indonesia (SEKI) yang diterbitkan Bank Indonesia untuk data IHGS, indeks harga konsumen, suku bunga, kurs dan nilai tukar serta Wall Street Journal untuk memperoleh data Dow Jones Index (DJI), Strait Time Index (STI), dan Hang Seng Index (HSI).

Alat analisis yang digunakan dalam penelitian ini adalah regresi berganda model dinamis yaitu dengan menggunakan Model Koreksi Kesalahan (Error Correction Model). Adapun tahapan pengolahan yang digunakan untuk pengujian hipotesis dengan model ECM adalah :

\section{Uji akar-akar unit (Unit Root)}

Pengujian Akar-Akar Unit (Unit Roots Test) dilakukan untuk menguji apakah masingmasing variabel yang digunakan dalam penelitian bersifat stasioner pada derajat nol (level 0) atau derajat satu atau lebih tinggi. Jika variable tersebut stationer pada level, maka variabel tersebut dinamakan Integrated Order Zero $\left(\mathrm{I}_{0}\right)$. Jika variabel tersebut hanya menjadi stationer setelah dilakukan differense 1 kali, maka variabel tersebut dinamakan Integrated Order One $\left(\mathrm{I}_{1}\right)$. Pengujian unit root dilakukan dengan menggunakan Augmented Dickey Fuller (ADF). Menurut Thomas (1997) alam Marciano (2009), suatu variabel dianggap stasioner jika rata-rata, varian dan covariannya konstan sepanjang waktu. Hipotesis yang diajukan dalam peneliitian adalah: $\mathrm{H}_{\mathrm{o}}$ : data tidak stasioner

$\mathrm{H}_{\mathrm{a}}$ : data stasioner

Pengambilan keputusan dilakukan dengan kriteria.

- Jika nilai statistik DF dan ADF > nilai tabel maka $\mathrm{H}_{\mathrm{o}}$ ditolak atau data stasioner.

- Jika nilai statistik DF dan ADF < nilai tabel maka $\mathrm{H}_{\mathrm{o}}$ diterima atau data tidak stasioner. Kriteria alternatif, yang digunakan dalam 
penelitian ini adalah:

- Jika p value dari ADF $<0.05$ maka tolak H0

- Jika $\mathrm{p}$ value dari $\mathrm{ADF} \geq 0.05$ maka $\mathrm{H0}$ tidak dapat ditolak

\section{Uji Kointegrasi}

Pada saat pengujian kointegrasi semua variabel harus tidak stationer pada level tetapi stationer pada first difference, setelah itu digunakan untuk menguji apakah antara variabel independen dan variabel dependen dalam jangka panjang saling berhubungan. Tahapan pengolahan untuk uji kointgrasi :

a. Melakukan regresi linier harga saham dengan model

IHGS $=\mathrm{f}($ DJI, STI, HSE $)$

Dari model regersi diambil residual dari model

b. Melakukan uji stasioner untuk residual dengan hipotesis

$\mathrm{H}_{\mathrm{o}}$ : Error tidak stasioner (tidak terjadi kointegrasi)

$\mathrm{H}_{\mathrm{a}}$ : Error stasioner (terjadi kointegrasi)

Pengambilan keputusan dilakukan dengan kriteria

- Jika nilai statistik DF dan $\mathrm{ADF}>$ nilai tabel maka $\mathrm{H}_{\mathrm{o}}$ ditolak (model berkointegari).

- Jika nilai statistik DF dan ADF < nilai tabel maka $\mathrm{H}_{\mathrm{o}}$ diterima (model tidak berkointegrasi).

Kriteria alternatif, yang digunakan dalam penelitian ini adalah:

- Jika p value dari $\mathrm{ADF}<0.05$ maka tolak $\mathrm{H}_{0}$.

- Jika $\mathrm{p}$ value dari $\mathrm{ADF} \geq 0.05$ maka $\mathrm{H}_{0}$ tidak dapat ditolak.

\section{Pembentukan dan estimasi model ECM}

Jika terbukti ada kointegrasi, maka perlu dibuatkan model ECM demikian pula jika tidak terbukti ada kointegrasi maka ECM tidak dapat dilakukan.Model persamaan ECM pada jangka panjang yaitu :

$\mathrm{IHSG}=\mathrm{B}_{0}+\mathrm{B}_{1} \mathrm{DJI}+\mathrm{B}_{2} \mathrm{STI}+\mathrm{B}_{3} \mathrm{HSE}$

Model persamaan ECM pada jangka pendek yaitu :

DIHSG $=\alpha_{0}+\alpha D_{1} D J I+\alpha D_{2} S T I+\alpha D_{3} H S E+E C T+\varepsilon$

\section{Uji Hipotesis}

Metode pengambilan keputusan yang didasarkan dari analisis data, pernyataan atau dugaan mengenai satu atau lebih populasi. Pengujian hipotesis berhubungan dengan penerimaan atau penolakan suatu hipotesis. Pada pengujian hipotesis ini dilakukan untuk menguji apakah masing-masing variabel independen baik dalam jangka pendek maupun jangka panjang saling berpengaruh.

Model ECM yang digunakan untuk penelitian ini adalah :

$$
\begin{aligned}
\Delta \mathrm{IHSG}= & \mathrm{b}_{\mathrm{o}}+\mathrm{b}_{1} \Delta \mathrm{DJI}+\mathrm{b}_{2} \Delta \mathrm{STI}+\mathrm{b}_{3} \Delta \mathrm{HSE}_{3} \\
& +\mathrm{b}_{4} \mathrm{DJI}+\mathrm{b}_{5} \mathrm{STI}+\mathrm{B}_{6} \mathrm{HSEt}_{{ }_{1}}+\mathrm{E}
\end{aligned}
$$

\section{Dimana}

IHSG = Indeks Harga Saham Gabungan

DJI = Down Jones Index

STI = Strait Time Index

HSE $=$ Hang Seng Index

$\mathrm{b}_{1}$ sampai $\mathrm{b}_{3}$ adalah koefisien jangka pendek.

$\mathrm{B}_{4}$ sampai $\mathrm{b}_{6}$ adalah koefisien jangka panjang.

Analisa hipotesanya yaitu :

1. $\mathrm{H}_{01}: \mathrm{B}_{1}=0$ artinya $\mathrm{B}_{1}$ tidak berpengaruh signifikan terhadap IHSG.

$\mathrm{H}_{01}: \mathrm{B}_{1} \neq 0$ artinya $\mathrm{B} 1$ berpengaruh signifikan terhadap IHSG

2. $\mathrm{H}_{02}: \mathrm{B}_{2}=0$ artinya $\mathrm{B}_{2}$ tidak berpengaruh signifikan terhadap IHSG.

$\mathrm{H}_{02:} \mathrm{B}_{2} \neq 0$ artinya $\mathrm{B}_{2}$ berpengaruh signifikan terhadap IHSG

3. $\mathrm{H}_{03}: \mathrm{B}_{3}=0$ artinya $\mathrm{B}_{3}$ tidak berpengaruh signifikan terhadap IHSG.

$\mathrm{H}_{03}: \mathrm{B}_{3} \neq 0$ artinya $\mathrm{B}_{3}$ berpengaruh signifikan terhadap IHSG

4. $\mathrm{H}_{04}: \mathrm{B} 4=0$ artinya $\mathrm{B}_{4}$ tidak berpengaruh signifikan terhadap IHSG.

$\mathrm{H}_{04}: \mathrm{B}_{4} \neq 0$ artinya $\mathrm{B}_{4}$ berpengaruh signifikan terhadap IHSG

Pengambilan keputusan dilakukan dengan kriteria jika P- Value dari t statistics $<0,05, \mathrm{H}_{0}$ ditolak jika P-value dari t statistics $\geq 0,05 \mathrm{H}_{0}$ diterima. 


\section{HASIL dan PEMBAHASAN}

Hasil

Hasil pengolahan untuk statistik deskriptif variabel penelitian dapat diihat untuk variabel IHSG diperoleh nilai rata-rata sebesar 3471.98 dan standar deviasi 1337,39 menunjukkan adanya fluktuasi yang cukup besar dari pergerakan IHSG selama periode 2006.1 sampai dengan 2016.12. Hal ini dapat dilihat dari nilai minimum sebesar 1216.14 dan nilai maksimum dari IHSG sebesar 5518.68. Jika dilihat menurut perkembangan IHSG selama periode Januari 2006 sampai Desember 2016 menunjukkan bahwa kinerja pasar modal di Indonesia secara keseluruhan mengalami peningkatan kinerja seperti ditunjukkan dengan pergerakan IHSG yang semakin meningkat dari tahun ke tahun. Untuk lebih jelasnya dapat dilihat pada tabel berikut.

Pengolahan model ECM dilakukan dengan 3 tahapan yaitu pengujian akar-akar unit dan derajat intergrasi, pengujian kointegrasi dan pengujian hipotesis model ECM baik untuk jangka pendek maupun untuk jangka panjang.

\section{Pengujian Akar-akar unit dan Derajat Integrasi}

Hasil pengolahan ditunjukkan dengan dari tabel dapat dilihat bahwa dari 4 variabel yang digunakan yaitu, variabel IHSG, ,DJI, STI, HSE semuanya tidak stationer pada level, seperti ditunjukkan oleh nilai prob dari statistik pengujian DF $>0,05$. Model ECM mensyaratkan bahwa seluruh variabel harus tidak stasioner pada derajat level nol dan mencapai stasioner pada derajat integrasi pertama.

\section{Pengujian Kointegrasi}

Pengujian ini dilakukan untuk menguji apakah dalam jangka panjang ada hubungan antara variabel independen dengan variabel dependen. Pengujian kointegrasi dilakukan dengan melakukan pengujian stasioner dari residual model jangka panjang.

Dalam menganalisauji unitroot (stasioneritas) atas RESID01 memberikan hasilnya sebagai berikut : P. Value $=0.0004(<0.05)$ artinya sudah stationer. Jadi ada kointegrasi antara variabelvariabel yang digunakan tadi. Coef resid01(-1) adalah -0.196531 (ini minus, jadi memenuhi syarat sebagai adjustment factor). Setiap bulan menyesuaikan senilai 28.2. Dengan nilai koefisien residual tersebut dihitung $(1 / 0,196531)=5 \mathrm{bu}-$ lan akan mencapai titik ekuilibrium apabila terjadi gejolak yang dipengaruhi oleh variabel independen.

\section{Pembahasan}

\section{Model Jangka Pendek}

Temuan dari hasil model jangka pendek dapat dijelaskan sebagai berikut:

\begin{tabular}{|c|c|c|c|c|}
\hline \multicolumn{5}{|c|}{ Model ECM Jangka Pendek } \\
\hline \multicolumn{5}{|c|}{$\begin{array}{l}\text { Dependent Variable: DIHSG } \\
\text { Method: Least Squares } \\
\text { Date: 07/14/17 Time: } 16: 30 \\
\text { Sample (adjusted): 2006M02 2016M12 } \\
\text { Included observations: } 131 \text { after adjustments }\end{array}$} \\
\hline Variable & Coefficient & Std. Error & t-Statistic & Prob. \\
\hline C & 27.93354 & 15.17985 & 1.840173 & 0.0682 \\
\hline DDJ & 0.024145 & 0.030142 & 0.801036 & 0.4247 \\
\hline DSTI & 0.001604 & 0.000389 & 4.118322 & 0.0001 \\
\hline DHSE & -0.012726 & 0.013078 & -0.973097 & 0.3324 \\
\hline RESID01(-1) & -0.196531 & 0.054222 & -3.624531 & 0.0004 \\
\hline R-squared & 0.547719 & \multicolumn{2}{|c|}{ Mean dependent var } & 31.04588 \\
\hline Adjusted R-squared & 0.521980 & \multicolumn{2}{|c|}{ S.D. dependent var } & 171.0817 \\
\hline S.E. of regression & 118.2842 & \multicolumn{2}{|c|}{ Akaike info criterion } & 12.44318 \\
\hline Sum squared resid & 1720912. & \multicolumn{2}{|c|}{ Schwarz criterion } & 12.61877 \\
\hline Log likelihood & -807.0284 & \multicolumn{2}{|c|}{ Hannan-Quinn criter. } & 12.51453 \\
\hline F-statistic & 21.27927 & \multicolumn{2}{|c|}{ Durbin-Watson stat } & 1.859233 \\
\hline Prob(F-statistic) & 0.000000 & & & \\
\hline
\end{tabular}

\section{Koefisien Determinasi}

Model fit yang dihasilkan (R2 adjusted) sebesar 0,52198 menunjukkan bahwa variasi atau perilaku dari variabel independen yaitu DJI, HSE dan STI mampu menjelaskan variasi dari variabel dependennya yaitu IHSG sebesar 52,19\% sedangkan sisanya yaitu $47,8 \%$ adalah variasi dari variabel independen lain yang mempengaruhi IHSG tetapi tidak dimasukkan dalam model.

\section{Uji Dampak Simultan (uji F)}

Pengujian secara simultan dengan uji $\mathrm{F}$ menghasilkan nilai $\mathrm{p}$-value dari $\mathrm{F}$ sebesar $0,000<0,05$ yang artinya $\mathrm{H}_{0}$ ditolak $\left(\mathrm{H}_{\mathrm{a}}\right.$ diterima) sehingga dapat disimpulkan bahwa terbukti secara statistik paling tidak terdapat 1 variabel independen yang berpengaruh signifikan terhadap variabel dependennya. 


\section{Uji dampak Parsial (uji t)}

Hasil pengujian secara parsial individu dalam model jangka pendek dapat dijelaskan sebagai berikut:

1. Koefiesien estimasi harga saham Dow Jones menghasilkan nilai sebesar 0.024145. Dengan nilai prob dari t ststaistik sebesar 0,4247>0,05 maka $\mathrm{H}_{\mathrm{o}}$ diterima sehingga terbukti secara statistik pengaruh positif dari harga saham Dow Jones terhadap IHSG tidak signifikan.

2. Koefisien estimasi harga saham Strait Time ditunjukkan dengan nilai sebesar 0,001604 yang artinya meningkatnya harga saham Hang Seng akan meningkatkan IHSG dan sebaliknya. Dengan nilai prob dari t statistik sebesar $0,0001<0,05$ maka $\mathrm{H}_{\mathrm{o}}$ diterima sehingga terbukti secara statistik pengaruh positif dari harga saham Strait Time terhadap IHSG signifikan.

3. Koefisien estimasi harga saham Hang Seng ditunjukkan dengan nilai sebesar -0,012726. Dengan nilai prob dari t ststaistik sebesar $0,3324>0,05$ maka $\mathrm{H}_{\mathrm{o}}$ diterima sehingga terbukti secara statistik pengaruh negatif dari harga saham Hang Seng terhadap IHSG tidak signifikan.

\section{Model Jangka Panjang}

Temuan dari hasil model jangka pendek dapat dijelaskan sebagai berikut :

\begin{tabular}{|c|c|c|c|c|}
\hline \multicolumn{5}{|c|}{ Model ECM Jangka Panjang } \\
\hline \multicolumn{5}{|c|}{$\begin{array}{l}\text { Dependent Variable: IHSG } \\
\text { Method: Least Squares } \\
\text { Date: 07/14/17 Time: 16:19 } \\
\text { Sample: 2006M01 2016M12 } \\
\text { Included observations: } 132\end{array}$} \\
\hline Variable & Coefficient & Std. Error & t-Statistic & Prob. \\
\hline C & -3643.353 & 427.8413 & -8.515666 & 0.0000 \\
\hline ال ال & 0.086340 & 0.020311 & 4.250841 & 0.0000 \\
\hline STI & 0.001581 & 0.000372 & 4.244650 & 0.0000 \\
\hline HSE & -0.010463 & 0.013432 & -0.778952 & 0.4375 \\
\hline R-squared & 0.977618 & \multicolumn{2}{|c|}{ Mean dependent var } & 3471.977 \\
\hline Adjusted R-squared & 0.976544 & \multicolumn{2}{|c|}{ S.D. dependent var } & 1337.586 \\
\hline S.E. of regression & 204.8575 & \multicolumn{2}{|c|}{ Akaike info criterion } & 13.53408 \\
\hline Sum squared resid & 5245822. & \multicolumn{2}{|c|}{ Schwarz criterion } & 13.68695 \\
\hline Log likelihood & -886.2492 & \multicolumn{2}{|c|}{ Hannan-Quinn criter. } & 13.59620 \\
\hline F-statistic & 909.9746 & \multicolumn{2}{|c|}{ Durbin-Watson stat } & 0.560226 \\
\hline Prob(F-statistic) & 0.000000 & & & \\
\hline
\end{tabular}

\section{Koefisien Determinasi}

Model fit yang dihasilkan ( $\mathrm{R}^{2}$ adjusted) sebesar 0.976544 menunjukkan bahwa variasi atau perilaku dari variabel independen yaitu DJI, HSE dan STI mampu menjelaskan variasi dari variabel dependennya yaitu IHSG sebesar 97,65\% sedangkan sisanya yaitu $2,34 \%$ adalah variasi dari variabel independen lain yang mempengaruhi IHSG tetapi tidak dimasukkan dalam model.

\section{Uji Dampak Simultan (Uji F)}

Pengujian secara simultan dengan uji $\mathrm{F}$ menghasilkan nilai p-value dari F sebesar 0,000< 0,05 yang artinya $\mathrm{H}_{\mathrm{o}}$ ditolak $\left(\mathrm{H}_{\mathrm{a}}\right.$ diterima) sehingga dapat disimpulkan bahwa terbukti secara statistik paling tidak terdapat satu variabel independen yang berpengaruh signifikan terhadap variabel dependennya.

\section{Uji Dampak Parsil (Uji t)}

Hasil pengujian secara parsial individu dalam model jangka pendek dapat dijelaskan sebagai berikut :

1. Koefisien estimasi harga saham Dow Jones menghasilkan nilai sebesar 0.086340 menunjukkan meningkatnya harga saham Dow Jones akan meningkatkan IHSG dan sebaliknya. Dengan nilai prob dari t ststaistik sebesar $0,0000<0,05$ maka $\mathrm{H}_{\mathrm{o}}$ ditolak sehingga terbukti secara statistik pengaruh positif dari harga saham Dow Jones terhadap IHSG signifikan.

2. Koefisien estimasi harga saham Strait Time ditunjukkan dengan nilai sebesar 0,001581 yang artinya menigkatnya harga saham Strait Time akan meningkatkan IHSG dan sebaliknya. Dengan nilai prob dari t ststaistik sebesar 0,0000

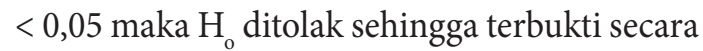
statistik pengaruh positif dari harga saham Strait Time terhadap IHSG signifikan.

3. Koefisien estimasi harga saham HSE ditunjukkan dengan nilai sebesar - 0,010463. Dengan nilai prob dari $\mathrm{t}$ ststaistik sebesar 0,4375 > 0,05 maka $\mathrm{Ho}_{\mathrm{o}}$ diterima dan $\mathrm{H}_{\mathrm{a}}$ ditolak sehingga terbukti secara statistik pengaruh negatif dari harga saham Strait Time terhadap IHSG tidak signifikan. 


\section{SIMPULAN}

Dow Jones Index dalam jangka pendek terbukti sebagai variabel independen yang berpengaruh tidak signifikan terhadap indeks harga saham gabungan (IHSG) tetapi dalam jangka panjang berpengaruh signifikan.

Strait Times Index dalam jangka pendek dan panjang terbukti sebagai variabel independen yang berpengaruh signifikan terhadap indeks harga saham gabungan (IHSG).

Hang Seng Index dalam jangka pendek dan panjang terbukti sebagai variabel independen yang berpengaruh tidak signifikan terhadap indeks harga saham gabungan (IHSG).

Secara simultan dalam jangka pendek dan panjang terbukti bahwa keseluruhan variabel yang digunakan berdampak signifikan terhadap IHSG.

\section{DAFTAR PUSTAKA}

Batareddy, M. (2012). The stability of long run relationship. A study on Asian emerging and developed stock market (Japan and US). International Journal of Emerging Market Vol.7 no.1, 2012 pp 31-48.

Dhanaraj, S.,\& Gopalaswany, A.K. (2013). Dynamic interdepenndence between US an Asian Market: an Empirical study. Journal of financial Economic Policy Vol. 5, No. 2.

Ekadjaja, M. (2016, July). Pengaruh Indeks Bursa Regional terhadap Indeks Harga Saham Gabungan (IHSG). Jurnal Ekonomi Vol.XX, No. 02: 193-211.

Murni, S. (2015). Analisis Faktor Makroekonomi terhadap kinerja pasar Saham di beberapa Negara Asia. Jurnal EMBA vol.3 No.3 2015. Hal: 1309-1318.

Mandasari, N.P. (2013). Pengaruh Indeks Saham Luar Negeri terhadap IHSG Untuk Keputusan Investasi. Jurnal Jurnal Ilmu dan Riset Manajemen Vol. 2. No. 6.

Nasution, Anwar. (2003). Masalah-Masalah Stabilitas Keuangan (Online). (www.lfip.org/ english/pdf/bali-seminar, diakses 10 Oktober 2008).

Naik, P.K \& Padhi, P. (2015). Interaction of
Institutional Investment Activity and Stock Market Volatility: Evidence from India. AsiaPacific Journal of Management Research and Innovation Vol 11, Issue 3.

Nezky, M. (2013, January). Pengaruh Krisi Ekonomi Amerika Serikat terhadap Bursa Saham dan Perdagangan Indonesia. Buletin Ekonomi Moneter \& Perbankan.

Nachrowi, N.D., Usman, H.(2006). Pendekatan Populer dan Praktis Ekonomika Untuk Analisis Ekonomi dan Keuangan. Lembaga Penerbit Fakultas Ekonomi Universitas Indonesia.

Seth, N. (2015). International stock market efficient and integration. Evidence from Asian an US Markets. Journal of Advances in Management Research Vol. 12 No. 2, 2015 pp.88-106. Emerald Group Publishing Limited.

Rahamis, Y. (2014). Analisis Komparasi Kinerja Pasar Modal Di Indonesia, Hongkong, China, Inggris, dan Amerika. Jurnal Riset Bisnis dan Manajemen Vol.2 ,No.3, 2014:87-104.

Sukirno, S. (2013). Pengantar Teori Makroekonomi. PT Raja Grafindo Persada, Jakarta.

Sukirno, S. (2015). Makroekonomi Teori Pengantar. Edisi 3.

Utama, I.W .\& Artini, L.G. (2015, February). Pengaruh Indeks Bursa Dunia pada Indeks harga Saham Gabungan Bursa Efek Indonesia. Jurnal Manajemen, Strategi Bisnis dan Kewirausahawan Vol. 9 No.1.

Wangbangpo, P. (2000). Dynamic Analysis on ASEAN Stock Market. A Dissertation Submitted in Partial Fulfilment of the Requirement for the Doctor Philosophy Degree. Department of Economic in the graduate School Southern Illinois University at Carbondale.

www.bi.go.id. 